being laid by stray beetles, if the tobacco is exposed during the manufacture of cigars. In order to guard against this, cigars before leaving the factory should be fumigated thoroughly in a small room with $\mathrm{HCN}$, then aired and packed. This would not cost much but it would practically insure the manufacturer's business.

The writer knows several parties, who turn out cigars that are free from the pest, although the tobacco was formerly infested. But by steaming the tobacco the pest was killed and then the tobacco is manufactured in a different town where there are no insects to reinfęst.

If a single beneficial suggestion has been given or if the paper will induce some one to rid their house of the cigarette beetle by means of $\mathrm{HCN}$, or otherwise, the writer feels that the paper has not been in vain.

For a fuller account of the cigarette beetle the reader is advised to consult Farmers' Bulletin No. 120 of the U. S. Department of Agriculture.

\title{
STUDIES OF THE DEVELOPMENT OF EUPELMUS ALLYNII FRENCH AND STICTONOTUS ISOSOMATUS RILEY
}

\author{
By E. O. G. Kelly, Bureau of Entomology
}

These two valuable parasites have been known to seience and entomologists for about twenty-eight years. In 1881 and 1882, Prof. G. H. French reared adults of what is known as Eupelmus allynii from wheat straw and described the insect as Isosoma allynii. Professor French and Dr. C. V. Riley discovered that the insect was parasitic on Isosoma grande and that it did not belong to the genus Isosoma. Doctor Riley decided that the species belonged to the genus Eupelmus and it still remains Eupelmus allynii.

During this same winter of 1882, Doctor Riley reared and described adults of Stictonotus isosomatis parasitic on Isosoma grande.

Doctor Riley, Doctor Forbes, Professor French, Professor Webster and many other students of insects affecting cereal and forage crops have reared these parasites from the straw; and considerable has been written regarding their economic importance, but the larval habits have not heretofore been described.

The females of these two species have rather long pointed ovipositors with which they readily pierce the hard straw containing Isosoma sp., and puparium of the Hessian fly. The females put their 
eggs into the cells of Isosoma larvæ, but not always on the larva itself; and inside the puparium of the Hessian fly, but, again, not into the larva.

Life History. During the early fall the egg hatches in three to six days, after deposition the tiny larva attaches itself to the host larva and sucks its life blood; they do not consume the skin of the host. The larva reach maturity in six to fifteen days and pupate in the Isosoma cell within the straw, and within the puparium of the Hessian fly. The pupæ are naked in both species. The pupal period ranges from seven to twelve days.

Eupelmus allynii hibernates in both the larval and pupal stages. Stictonotus isosomatus hibernates as pupa. Both species are found in cells of Isosoma sp. and in pupariæ of Hessian fly at this date (November 26, 1909). There were two distinct broods this year one in early summer, the other in fall.

Descriptions. The eggs of the two species are quite different; that of Eupelmus is whitish in color and pedicellate. The bulb is elliptical in form, about $.25 \mathrm{~mm}$. in length and $.12 \mathrm{~mm}$. in width; the pedicel is slender, of uniform diameter and nearly as long as the bulb. The egg of Stictonotus is whitish in color, elliptical in form and about $.3 \mathrm{~mm}$. long and $.12 \mathrm{~mm}$. in width.

The larva of the two species, though quite similar when viewed without the aid of a magnifier, magnified they present some striking differences. Eupelmus larve have four distinct rows of bristles on the body, each segment having two dorsal and two ventral; the head bears two tiny brown mandibles; they vary in size from 2 to $4 \mathrm{~mm}$. in length. Stictonotus larva are more cylindrical, have no bristles and no mandibles; they are 2 to $4 \mathrm{~mm}$. in length. Both species are yellowish white in color.

The pupæ are quite different, Eupelmus being black with light rings on the abdomen, while Stictonotus has a dark thorax and yellowish abdomen.

A very interesting feature of parasitism presented itself while these studies were in progress. Eupelmus allynii larvæ were found attached to pupæ of Stictonotus isosomatis and reared to adult; and Stictonotus isosomatis larva WERE FOUND ATTACHED to pupæ of Eupelmus allynii and reared to adult. Parasitic larvæ were found attached to parasitic larvæ whose identity could not be determined -because of mutilation or because of the desire of the writer to rear the secondary parasite. However, both species were reared from these larve, the host not being determined. In several instances tertiary parasites were found but failed to mature. 
Some undetermined secondary parasites were reared from the larvge of both Eupelmus and Stictonotus.

The writer is indebted to Mr. T. H. Parks, agent and expert, in the Bureau of Entomology, for his kind assistance in collecting and rearing these parasites.

\section{COLLEMBOLA AS INJURIOUS INSECTS}

By Walter E. Coldinge, M. Sc., F. L. S., F. E. S., Berkhamsted, England

In a communication read at the Oxford Meeting of the Association of Economic Biologists ${ }^{1}$ I drew attention to the part that various species of Collembola play as injurious insects and instanced many cases reported by Carpenter, ${ }^{2}$ Curtis,, ${ }^{3}$ Ormerod, ${ }^{*}$ Murray, ${ }^{5}$ Guthrie, ${ }^{6}$ myself, ${ }^{7}$ and others, where they were the direct cause of damage to roots and seeds of healthy plants, and I incidentally pointed out, in referring to the nature of the injury, that they also play an important part in exposing different plants to the attacks of fungi by the injury they cause in wounding their surfaces.

Since then two facts have come to light which have an important bearing upon the subject.

The experiment I made I described as follows:

"During the past twelve months very careful observations have been made upon a series of common species which have fully established the fact that to orchards, numerous bulbs, beans and peas, the Collembola are distinctly injurious.

"The method adopted has been as follows:

"Shallow boxes, containing about four inches of moist soil, have been used, and into these perfectly healthy bulbs and beans have been placed. Into each box examples of different species of Collembola have been placed. The tops of the boxes in some cases were covered with a sheet of glass, and in others with a piece of wood.

"After the experiments were completed the soil and diseased bulbs were carefully examined, and apart from fungi no other pests were

${ }^{1}$ Journ. Economic Biol., 1909, Vol. IV, p. 83-86.

${ }^{2}$ Proc. Assoc. Econ. Biol., 1905, Vol. I, p. 14.

- Farm Insects, p. 432.

${ }^{4}$ Rpt. Obs. Inj. Insects for 1904, p. 110.

${ }^{5}$ Economic Entomology, Aptera, p. 404.

- The Collembola of Minnesota, 1903, p. 4.

- Rpt. on Inj. Insects for 1905, p. 10. 